\title{
Persepsi Pekerja Terhadap Work From Home (WFH) di Masa Pandemik Covid-19
}

\author{
Yosart Adi Suyoso, Ana Yuliana, Muhammad Rizqi Agustino, \\ Regy Citra Perdana, Dedi Hartawan. \\ yoosart@gmail.com
}

\begin{abstract}
This study aims to perceptions of Work From Home (WFH) received by workers who previously worked regularly at the office. This change makes the workers change physically and mentally. The research method used is a qualitative method with interviews with respondents in accordance with the requirements. The technique used is the documentation technique for collecting data from various sources and information. The type of data is secondary data from research results sourced from the media and news.
\end{abstract}

Keywords: perceptions, Work From Home,Covid-19.

\begin{abstract}
ABSTRAK- Penelitian ini bertujuan untuk mengetahui persepsi pekerja terhadap Work From Home (WFH) yang dirasakan oleh para pekerja yang sebelumnya terbiasa harus bekerja secara rutin kekantor. Perubahan ini membuat para pekerja tersebut mengalami perubahan secara mental dan fisik. Metode penelitian yang digunakan adalah metode kualitatif dengan melakukan wawancara kepada responden yang sesuai dengan persyaratan. Teknik yang digunakan yaitu teknik dokumentasi untuk mengumpulkan data dari berbagai sumber dan informasi. Jenis data berupa data sekunder hasil penelitian terdahulu dan informasi yang bersumber dari media dan berita.
\end{abstract}

Kata kunci : Persepsi, Work From Home, Covid-19

\section{PENDAHULUAN}

Pandemi Covid-19 membawa perubahan hampir disemua sektor kehidupan, Hal ini membuat terjadinya perubahan dan peraturan dari pemerintah agar mencegah virus tersebut semakin meluas. Salah satu dari peraturan pemerintah untuk mencegah penyebaran Covid 19 adalah Pembatasan Sosisal Bersekala Besar (PSBB), peraturan pemerintah tersebut membuat kotakota besar membatasi jarak antar warganya bila berkumpul dan membatasi acara-acara yang menimbulkan jumlah masa yang berjumlah besar untuk di tiadakan sementara. Pembatasan Sosial Berskla Besar (PSBB) membuat para pengambil keputusan pada perusahaan untuk memperkerjakan karyawannya dari rumah atau dikenal dengan Work From Home (WFH)

Work From Home (WFH) sekarang ini menjadi pilihan kebanyak pekerja, apalagi bagi para generasi milenial saat ini tidak perlu berangkat ke kantor sehingga tidak banyak menyita waktu. Hanya menggunakan baju yang layak dan persiapan yang mencukupi kemudian membuka laptop dari rumah dan bekerja. Situasi terkini dunia WHO telah menyatakan bahwa pandemi virus Covid-19 berada di seluruh dunia. Presiden Indonesia saat ini bapak Joko Widodo dalam pidatonya mengintruksikan bahwa masyarakat Indonesia diharap mengurangi kegiatan di luar rumah untuk hal-hal yang dirasa tidak penting dan mendesak. Beliau juga berpesan untuk menerapkan sistem kerja Work From Home (WFH), sekolah serta perkuliahan dilakukan secara daring. Penerapan kebijakan tersebut merupakan langkah strategis yang diambil oleh pemerintah dalam mencegah wabah virus Covid-19 semakin menyebar ke seluruh Indonesia .Work From Home untuk bebrapa bidang memang belum bisa dilaksanakan, apalagi kesiapan dari perusahaan semdiri yang belum tentu siap dengan sistem Work From Home (WFH).

Rekomendasinya bagi pihak perusahaan dan pembisnis dapat menggunakan aplikasi-aplikasi yang dapat menunjang aktivitas Work From Home (WFH) agar hasilnya dapat lebih maksimal. Work From Home (WFH) yang dilaksanakan sekarang merupakan tindak lanjut dari himbauan Presiden Joko Widodo pada konferensi pers di Istana Bogor Jawa Barat (15 Maret 2020). Presiden menghimbau agar masyarakat meminimalisasi penyebaran dari virus corona tipe baru (SARS-CoV-2) penyebab Covid-19, masyarakat diminta untuk belajar, bekerja,dan beribadah di rumah. Himbauan ini, khususnya bagi para Aparatur Sipil Negara, hal ini direspon dan telah ditindaklanjuti oleh Menteri Pendayagunaan Aparatur Negara dan Reformasi Birokrasi melalui Surat Edaran nomor 19 Tahun 2020 tentang Penyesuaian Sistem Kerja Aparatur Sipil Negara dalam Upaya Pencegahan Covid-19 di Lingkungan 
Instansi Pemerintah. Isinya, ASN dapat bekerja di rumah atau tempat tinggal mereka, tetapi tetap dipastikan ada dua level pejabat struktural tertinggi yang bekerja dari kantor. Selain itu, terdapat larangan kegiatan tatap muka secara langsung yang menghadirkan peserta dalam jumlah banyak untuk dapat ditunda atau dibatalkan sementara. Penelitian ini bertujuan untuk mengetahui persepsi pekerja terhadap diterapkannya Work From Home (WFH) dimasa pandemi Covid-19.

\section{PERSEPSI}

\section{KAJIAN PUSTAKA}

Persepsi akan berhubungan dengan perilaku seseorang dalam mengambil keputusan terhadap apa yang dikehendaki [1]. Menurut Schiffman dan Kanuk merupakan suatu proses yang membuat seseorang untuk memilih, mengorganisasikan dan menginterprestasikan rangsangan- rangsangan yang diterima menjadi suatu gambaran yang berarti dan lengkap tentang dunianya [2]. Berdasarkan pengertian diatas dapat disimpulkan bahwa persepsi merupakan proses pengambilan keputusan yang dilakukan secara terorganisir secara lengkap sehingga mempengaruhi keputusan yang di ambil.

\section{WORK FROM HOME (WFH)}

Richardson dan Writer, (2017) berpendapat bahwa Work From Home (WFH) adalah hasil pemanfaatan teknologi modern, yang mengakibatkan peningkatan kredibilitas yaitu meningkatkan penggunaan internet untuk rapat secara daring dan berinteraksi secara daring yang membuat pekerjaan lebih mudah dan lebih sederhana. Sisi positif dari diberlakukannya Work From Home (WFH) adalah karyawan dapat bekerja sesuai dengan kenyamanan mereka, dan dapat memulai pekerjaan sesuai dengan keinginan mereka. Selanjutnya dampak negatif Work From Home (WFH) seperti keterlambatan dalam rapat secara daring dan pengiriman pekerjaan yang tidak tepat waktu.

\section{PANDEMI VIRUS CORONA / COVID 19}

Persebaran virus corona atau covid-19 menjadi perhatian seluruh negara. Word Health Organization (WHO) pada tanggal 11 Maret 2020 secara resmi mengumumkan peningkatan status dari epidemi ke pandemi. Penetapan status pandemi dilakukan dengan mempertimbangkan penyakit yang bersifat menular dan menyebar ke banyak wilayah atau negara. Dampak wabah Covid-19 dapat terlihat hampir di seluruh sektor kehidupan masyarakat dunia.

Covid-19 adalah penyakit yang menular disebabkan oleh jenis coronavirus yang menyebabkan infeksi pada saluran pernapasan manusia, mulai dari gejala batuk pilek hingga yang lebih serius seperti Middle East Respiratory Syndrome (MARS) dan Severe Acute Respiratory Syndrome (SARS) (WHO,2020). COVID-19 adalah penyakit baru disebabkan oleh infeksi Severe Acute Respiratory Syndrome Coronavirus 2 (SARS-CoV-2) yang dapat menyebabkan gangguan pada pernapasan dan radang paru (WHO,2020).

\section{METODE PENELITIAN}

Menggunakan metode riset kualitatif dengan menekankan pengembangan pertanyaan riset, penentuan responden yang tepat dan kualitas data yang diperoleh [3]. Teknik pengumpulan data dilakukan dengan wawancara kepada responden yang memenuhi persyaratan yaitu dengan kriteria responden yang bekerja Secara Work From Home (WFH) akibat pandemi Covid19. Serta menggunakan teknik dokumentasi sebagai suatu cara untuk mengumpulkan data dari berbagai sumber dan informasi. Jenis data berupa data sekunder hasil penelitian terdahulu. Data sekunder adalah data yang mengacu pada informasi yang dikumpulkan dari sumber yang telah ada [4].

\section{HASIL DAN PEMBAHASAN}

1. Berdasarkan hasil wawancara dari lima responden, 4 responden mengatakan setuju dengan penerapan Work From Home (WFH) dan satu orang responden tidak setuju dengan penerapan Work From Home (WFH).

2. Alasan yang menyatakan setuju dengan penerapan Work From Home (WFH) dikarenakan dapat memiliki waktu bersama dengan keluarga menjadi lebih banyak .

3. Berdasarkan alasan dari responden yang menyatakan tidak setuju dengan diterapkannya Work From Home (WFH) dikarenakan kurangnya alat penunjang yang dibutuhkan untuk melakukan pekerjaannya di rumah.

4. Dari hasil penelitian sebelumnya Di antara total 50 responden, 44 persen $(n=22)$ sudah menikah dan 56 persen $(\mathrm{n}=28)$ adalah lajang. Berkenaan dengan kemauan untuk bekerja dari rumah, dari 22 responden, 8 responden yang sudah menikah tidak setuju, 4 responden sangat tidak setuju, 8 
responden setuju dan 2 responden sangat tidak setuju.

5. Mengenai kesediaan untuk bekerja dari rumah, dari antara 28 responden, 2 responden tidak setuju dan 2 responden sangat tidak setuju, 20 responden setuju, dan 4 responden sangat setuju. Ditemukan bahwa mayoritas responden yang ada menikah tidak mau bekerja dari rumah dibandingkan dengan responden yang masih lajang.

6. Penelitian terdahulu juga menemukan bahwa 6 responden sangat setuju bahwa mereka bersedia bekerja dari rumah dan 28 responden setuju bahwa mereka bersedia bekerja dari rumah. Tetapi 17 responden dari 28 responden yang ada mau bekerja dari rumah tidak suka bekerja dari rumah. Bahkan jika responden mau bekerja, mereka menyatakan bahwa mereka tidak suka bekerja karena situasi yang tidak nyaman untuk bekerja dari rumah.

7. Penelitian terdahulu juga menemukan bahwa mayoritas responden yang memiliki anak tidak mau bekerja ketika dibandingkan dengan para responden yang tidak memiliki anak.

8. Studi ini mengungkapkan bahwa ini adalah pengalaman pertama 88 persen responden bekerja dari rumah untuk pertama kalinya, dan 12 persen sudah bekerja dari rumah ( 8 persen dari mengajar dan 4 persen dari sektor non-mengajar). Mayoritas responden mengalami pekerjaan dari rumah karena situasi yang timbul dari COVID 19.

Tabel Hasil Responden bersedia Work From Home dan responden suka Work from home

\begin{tabular}{|c|c|c|c|c|}
\hline & \multicolumn{3}{|c|}{ Saya suka work from home } & \multirow{2}{*}{$\begin{array}{l}\text { Total } \\
\text { Responden }\end{array}$} \\
\hline & & Iya & tidak & \\
\hline \multirow{4}{*}{$\begin{array}{l}\text { Saya } \\
\text { Bersedia } \\
\text { work from } \\
\text { home }\end{array}$} & sangat tidak & 0 & 6 & 6 \\
\hline & tidak setuju & 1 & 9 & 10 \\
\hline & setuju & 11 & 17 & 28 \\
\hline & sangat setuju & 5 & 1 & 6 \\
\hline Total & 17 & 33 & & \\
\hline
\end{tabular}

72 persen responden menemukan perbedaan dalam bekerja saat berada di kantor dan saat bekerja dari rumah.

\section{KESIMPULAN DAN SARAN}

1. Covid-19 merupakan pandemi yang telah menyebar ke seluruh dunia tidak terkecuali termasuk di Indonesia memberikan dampak yang besar terutama pada sisstem bekerja yang diterapkan oleh swasta maupun pemerintah.

2. Perusahaan yang dapat memperkerjakan karyawannya dari rumah di himbau untuk melakukan system Work from Home agar mencegah penyebaran Covid-19.

3. Penerapakan Work From Home (WFH) Belum Bisa Dilakukan secara merata pada semua bidang.

4. Masih terdapat karyawan yang tidak setuju dengan penerapan Work From Home karena masih terbatasnya peralatan yang dimiliki oleh karyawan.

5. Penerapan Work From Home (WFH) sebagi upaya pembatasan sosial pada

masyarakat memiliki taggapan yang bermacammacam seperti ada yang dapat menemukan dampak positif dari hal tersebut ada pula yang merasakan dampak negatif dari penerapan Work From Home (WFH).

\section{DAFTAR PUSTAKA}

[1] N. E. H.Baharuddin; Wahyuni, Teori Belajar\&Pembelajaran. 2015.

[2] L. G. Schiffman and L. L. Kanuk, Consumer Behavior 10th Edition. 2010.

[3] D. R. Cooper and P. S. Schindler, Business Research Methods Eleventh Edition. 2011.

[4] U. Sekaran, Research Methods for Business (Metodologi Penelitian Untuk Bisnis). 2011.

Kontan.co.id. (2020, $23 \quad$ April). https://pressrelease.kontan.co.id/release/allianzindonesia-kebijakan-work-from-home-tidakmengubah-tingkat-pelayanan-nasabah-danproduktivitas-Guru.

qwords.com. (2020, $23 \quad$ April). https://qwords.com/blog/apa-itu-work-fromhome/hukumonline.com. 